\title{
PENGARUH PEMBERIAN SARI TEBU TERHADAP KADAR KOLESTEROL DARAH PADA MENCIT
}

\author{
Rahma Widyastuti ${ }^{1}$ \\ 1) Prodi D3 Analis Kesehatan, FIK, Universitas Muhammadiyah Surabaya \\ blue4rahma@gmail.com
}

Tangal Submit:

27 November 2017

Tanggal Review:

12 Desember 2017

Tanggal Publish Online: 18 Desember 2017

\begin{abstract}
Sugarcane (Saccharum officinarum L.) is a plant known by the public as a refreshing drink that tastes sweet and the price is quite economical and readily available. Sugarcane contains octacosanol compounds that can lower cholesterol levels in the blood. Excessive cholesterol (hypercholesterolemia) a threat that is feared because as one of the causes of coronary heart disease (CHD) and stroke. The purpose of this study was to analyze the levels of cholesterol in mice, to analyze cholesterol levels in mice after the administration of sugar cane juice, to analyze the effect of sugar cane juice on cholesterol levels in mice. This type of research conducted by a group of experimental methods with populations of mice (Mus musculus) were obtained from farms Bojonegoro. The research sample selected by criteria mice aged 2-3 months, weighing between 20-40 grams of the male sex, the amount of sample used two groups of mice, each group consisted of 16 mice. From the results of blood cholesterol levels in mice after the administration of sugar cane juice, it is known that the average cholesterol level in the control group was $148.8750 \mathrm{mg} / \mathrm{dl}$ and value - average blood cholesterol treatment group was 118.2500 $\mathrm{mg} / \mathrm{dl}$. Statistically analyzed using a paired t test $\mathrm{t}$ value -3.799 obtained with significant value. $(p)=0.001$ which is less than 0.05 then there is the effect (Ho is rejected) $(t=-2.040$ table). So we can conclude there is the effect of sugar cane juice on blood cholesterol levels in mice.
\end{abstract}

Keywords : : Sugarcane, blood cholesterol levels

\section{PENDAHULUAN}

Kolesterol adalah termasuk keluarga lemak, zat ini merupakan salah satu dari komponen lemak itu sendiri. Kehadiran lemak sendiri dalam tubuh kita sesungguhnya memiliki fungsi sebagai zat gizi yang sangat diperlukan oleh tubuh disamping zat gizi lainnya seperti karbohidrat, protein, vitamin dan mineral. Lemak adalah cadangan energi yang memberikan kontribusi kalori paling tinggi. Sering kali kolesterol menjadi momok dan kerap dibicarakan sebagai sumber masalah kesehatan degeneratif dewasa ini (Harmanto, 2005).

Tidak banyak yang mengetahui bahwa hiperkolesterol merupakan faktor risiko penyebab kematian di usia muda. Berdasarkan laporan Badan Kesehatan Dunia pada tahun 2002, tercatat sebanyak 4,4 juta kematian akibat hiperkolesterol atau sebesar 7,9\% dari jumlah total kematian di usia muda. Padahal 
hiperkolesterol atau hiperlipidemia termasuk faktor risiko utama penyakit gangguan pembuluh darah seperti PJK. Sedangkan pada tahun 2010 stroke juga merupakan penyebab kematian nomor tiga setelah penyakit jantung dan kanker. Setiap detik ada orang meninggal akibat stroke dan setiap detik akan ada kasus baru stroke di seluruh dunia. 25\% angka kematian di Indonesia disebabkan oleh stroke dan penyakit jantung koroner. Kolesterol jahat (LDL) yang tidak terkontrol adalah salah satu faktor penyebabnya.

Hal ini sangat membahayakan sebab kelebihan kalori dari asupan makanan yang tidak digunakan, akan diubah oleh tubuh dan disimpan sebagai cadangan lemak. Semakin banyak kelebihan kalori tersebut. Keadaan tersebut apabila berlangsung terus menerus dapat menimbulkan dislipidemia, stroke, sindrom metabolik, bahkan penyakit jantung yang mematikan karena Menurut Survei Kesehatan Rumah Tangga (SKRT), PJK merupakan penyebab nomor satu kematian di Indonesia. Dislipidemia dapat dicegah dengan mengubah gaya hidup sehari-hari seperti memperhatikan pola makan yang sehat dan diimbangi dengan olahraga secara teratur.

Tebu (bahasa Inggris: sugar cane) adalah tanaman yang ditanam untuk bahan baku gula dan vetsin. Tanaman ini hanya dapat tumbuh di daerah beriklim tropis. Tanaman ini termasuk jenis rumput-rumputan. Di Indonesia tebu banyak dibudidayakan di pulau Jawa dan Sumatra. Sari tebu sangat di minati dan dikenal oleh masyarakat luas sebagai minuman segar yang rasanya manis serta harganya juga cukup ekonomis. Tebu mengandung senyawa octacosanol sejenis alkohol rantai panjang yang mampu menurunkan kadar kolesterol dalam darah. Keberadaan Saccharum officinarum L. yang sudah umum dalam masyarakat dan mudah didapatkan, diharapkan akan mempermudah edukasi dan pengenalan Saccharum officinarum L. kepada masyarakat sebagai salah satu bahan alternatif dalam mengurangi dislipidemia, mencegah penyakit jantung mematikan khususnya penderita hiperkolestrolemia.

Berdasarkan latar belakang diatas, maka peneliti merumuskan masalah sebagai berikut, Apakah ada pengaruh pemberian sari tebu terhadap kadar kolesterol pada mencit. Dari rumusan masalah tersebut dapat diambil tujuan dari penelitian yaitu, Menganalisis kadar kolesterol pada mencit. Menganalisis kadar kolesterol pada mencit setelah pemberian sari tebu. Menganalisis pengaruh pemberian sari tebu terhadap kadar kolestrol pada mencit. Manfaat Penelitian Bagi Masyarakat Dapat dijadikan tambahan informasi bahwa sari tebu juga berpengaruh terhadap kadar kolestrol seseorang. Bagi Institusi Menambah kepustakaan tentang pengaruh sari tebu terhadap kadar kolesterol serta dapat digunakan sebagai acuan dalam penelitian berikutnya.

\section{METODE PENELITIAN}

Penelitian ini dilakukan dengan metode eksperimen, dengan memberi perlakukan sari tebu (Saccharum officinarum 
L) terhadap kadar kolesterol darah mencit (Mus musculus). Sehingga dapat diketahui apa benar sari tebu dapat menurunkan kolesterol darah. Adapun rancangan penelitian yang digunakan adalah eksperimental laboratoris "Postes Only Control Group Design". Desain eksperimen ini, memungkinkan peneliti mengukur pengaruh perlakuan (intervensi) pada kelompok tersebut dengan kelompok kontrol.

Dalam penelitian ini yang menjadi populasi adalah sekelompok mencit (Mus musculus) yang diperoleh dari Perternakan Bojonegoro. Sampel penelitian ini adalah mencit dari spesies yang sama yaitu Mus musculus yang dibagi dalam 2 kelompok secara purposive sampling masing - masing terdiri dari 16 mencit dengan kriteria mencit yang berumur 2-3 bulan dengan berat badan antara 20-40 gram yang berjenis kelamin jantan karena hormon-hormon dalam tubuhnya relatif stabil . Untuk setiap pengulangan pada masing-masing perlakuan sebanyak 16x pengulangan, jadi kesuluruhan sampel yang digunakan $16 \times 2=32$,

Penelitian ini dilaksanakan di Fakultas Kedokteran Hewan Universitas Wijaya Kusuma bagian Laboratoriun Patologi di Jl. Dukuh Kupang Barat XVI/1 Surabaya. Waktu penelitian mulai pada bulan Februari - Juli 2012, Waktu pemeriksaan dilaksanakan pada tanggal 23-24 Mei 2012.

Variabel bebas adalah pemberian sari tebu (Saccharum officinarum L.) (Sari tebu dalam penelitian ini dikategorikan menjadi tanpa pemberian dan dengan pemberian $1 \mathrm{ml}$ secara oral pada mencit). Variabel terikat adalah kadar kolesterol darah mencit (Mus musculus) (angka yang menunjukan kadar kolesterol mg/dl yang diambil 24 jam setelah diberi sari tebu dan diberi makanan pakan standart yang diperiksa dengan cara strip test). Variabel kontrol adalah semua variabel yang diduga berpengaruh, tetapi pengaruhnya dicegah, misalnya sari tebu dan mencit, umur, berat badan, dan jenis kelamin dikontrol dengan jalan disamakan.

\section{Metode Pengumpulan Data}

Pengumpulan data dilakukan dengan cara uji laboratorium di Fakultas Kedokteran Hewan Universitas Wijaya Kusuma dengan tahap-tahap sebagai berikut:

a) Metode pemeriksaan, Pemeriksaan ini adalah menggunkan metode Electrochemical.

b) Prinsip : Sampel darah masuk atau dihisapkan kedalam stik test, maka akan terjadi reaksi antara kolesterol darah dengan bahan kimia atau reagen kering yang berada dalam stik kolesterol.

c) Alat dan Bahan : Tebu (Sacharum officinarum, Linn.). Mencit (Mus musculus), . Spuit 1cc, Makanan mencit, Alkohol 70\%, Tissue, Strip test, Alat GCU, Beaker glass, Saringan, Pengiling tebu, Kandang mencit

d) Pembuatan sari tebu, Sampel (tebu) yang akan dilakukan penelitian dibersihkan terlebih dahulu (sampai kulitnya terkelupas semua), kemudian sampel di 
giling pada alat pengilingan tebu hingga keluar air atau sari tebu kemudian saring dan ditampung pada beaker gelas.

e) Pemberian sari tebu dan pengambilan darah mencit, Terlebih dahulu siapkan mencit yang berumur 2-3 bulan karena sudah dewasa, dengan berat badan antara 20-40 gram jenis kelamin jantan, diambil 32 ekor, setelah itu mencit di adaptasi selama 2 hari di tempat perlakuan agar mencit tidak strees pada waktu eksperimen (perlakuan), kemudian mencit dibagi menjadi 2 kelompok. Setiap kelompok terdiri dari 16 ekor mencit kelompok pertama (A) adalah kontrol yang di beri aquades, sedangkan kelompok kedua (B) adalah kelompok perlakuan yang diberi sari tebu sebanyak $1 \mathrm{ml}$ dengan cara oral. Sebelum perlakuan mencit di puasakan selama 2 jam. Pengambilan darah mencit dilakukan sebelum perlakuan dan 24 jam setelah pemberian sari tebu, darah diambil dari ekor kemudian darah di masukkan ke stick test yang sudah siap.

f) Prosedur pemeriksaan kolesterol, Menyiapkan alat dan bahan yang akan digunakan dalam penelitian. Daerah yang akan ditusuk dilakukan disinfektan dengan kapas alkohol 70\%, tunggu sampai kering \pm 30 detik. Kemudian ditusuk dengan spuit 1cc. Setelah darah keluar, maka hapus tetesan pertama dengan kapas. Darah yang keluar berikutnya diteteskan pada stick test yang telah siap, dengan hitungan mundur dari 150 detik. Kemudian hasilnya akan tertera pada layar yang ada di alat GCU (Nugraha,2007).

\section{HASIL PENELITIAN}

Dari hasil uji yang telah dilakukan di Fakultas Kedokteran Hewan Universitas Wijaya Kusuma bagian Laboratoriun Patologi di $\mathrm{Jl}$. Dukuh Kupang Barat XVI/1 Surabaya didapatkan data hasil perhitungan kadar kolesterol darah mencit (Mus musculus) antara kelompok kontrol dan kelompok perlakuan, sehingga diperoleh data sebagai berikut :

Table 1. Data Hasil Uji Kadar Kolesterol Darah Mencit (Mus musculus)

\begin{tabular}{|c|c|c|c|c|c|}
\hline \multicolumn{3}{|c|}{ Kelompok Kontrol } & \multicolumn{3}{|c|}{ Kelompok Perlakuan } \\
\hline \multirow[t]{2}{*}{$\begin{array}{c}\text { Kode } \\
\text { Sampel }\end{array}$} & \multicolumn{2}{|c|}{$\begin{array}{c}\text { Kadar kolesterol } \\
(\mathbf{m g} / \mathbf{d l})\end{array}$} & \multirow[t]{2}{*}{$\begin{array}{c}\text { Kode } \\
\text { Sampel }\end{array}$} & \multicolumn{2}{|c|}{$\begin{array}{c}\text { Kadar kolesterol } \\
(\mathrm{mg} / \mathrm{dl})\end{array}$} \\
\hline & Sebelum & Sesudah & & Sebelum & Sesudah \\
\hline A1 & 110 & 106 & B1 & 163 & 126 \\
\hline A2 & 161 & 159 & B2 & 152 & 134 \\
\hline A3 & 188 & 186 & B3 & 130 & 121 \\
\hline A4 & 129 & 129 & B4 & 133 & 106 \\
\hline A5 & 152 & 153 & B5 & 102 & 96 \\
\hline A6 & 161 & 158 & B6 & 103 & 93 \\
\hline A7 & 134 & 134 & B7 & 138 & 117 \\
\hline A8 & 181 & 180 & B8 & 118 & 100 \\
\hline A9 & 161 & 160 & B9 & 137 & 108 \\
\hline A10 & 126 & 121 & B10 & 137 & 129 \\
\hline A11 & 128 & 128 & B11 & 118 & 100 \\
\hline A12 & 169 & 167 & B12 & 116 & 117 \\
\hline A13 & 100 & 100 & B13 & 135 & 105 \\
\hline A14 & 152 & 152 & B14 & 168 & 143 \\
\hline A15 & 181 & 181 & B15 & 142 & 145 \\
\hline A16 & 167 & 168 & B16 & 169 & 152 \\
\hline Jumlah & 2400 & 2382 & Jumlah & 2161 & 1892 \\
\hline $\begin{array}{l}\text { Rata- } \\
\text { rata }\end{array}$ & 150 & 148,875 & $\begin{array}{c}\text { Rata- } \\
\text { rata }\end{array}$ & 135,0625 & 118,25 \\
\hline
\end{tabular}

\section{Analisis data}

Dari data hasil uji kadar kolesterol darah mencit (Mus musculus) peneliti analisa dengan program statistik, berikut ini adalah hasil pengolahan data dengan menggunakan diagram adalah sebagai berikut : 


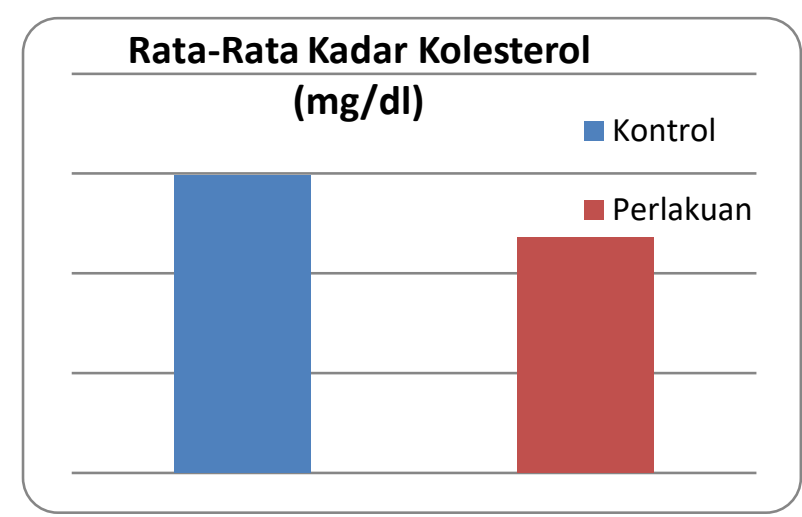

Gambar 4.1 Diagram rata - rata kadar kolesterol sesudah pemberian sari tebu

Berdasarkan tabel uji $\mathrm{T}$ berpasangan diatas menunjukkan bahwa ada pengaruh pemberian sari tebu terhadap kadar kolesterol pada mencit yang ditunjukkan dengan nilai $\mathrm{t}$ hitung $-3,799$ dengan nilai signifikan. $(p)=$ 0,001 dimana lebih kecil dari 0,05 maka ada pengaruh $($ Ho ditolak) $(\mathrm{t}$ table $=-2,040)$

\section{PEMBAHASAN}

Pada data hasil penelitian dapat dilihat rata-rata kadar kolesterol darah mencit pada tabel 4.1 kelompok kontrol sebelum perlakuan $(150 \mathrm{mg} / \mathrm{dl})$ dan sesudah perlakuan $(148,8750$ $\mathrm{mg} / \mathrm{dl}$ ) sedangkan kelompok perlakuan sebelum pemberian sari tebu $(135,0625 \mathrm{mg} / \mathrm{dl})$ dan sesudah pemberian sari tebu $(118,2500 \mathrm{mg} / \mathrm{dl})$.

Menurut hasil riset National center for scientific Research Havana Kuba. Octacosanol menekan sintesa kolesterol yang di produksi di dalam hati. Hal ini terlihat dari adanya pengaturan enzim reductase HMGCoA-Enzim yang membatasi laju sintesa kolesterol. Pengamatan jangka panjang terhadap konsumsi octacosanol membuktikan senyawa itu dapat menurunkan dan mengontrol kadar kolesterol darah tanpa efek samping. Pemberian octacosanol per hari menunjukkan penurunan total kolesterol 17,5\%, dan LDL-kolesterol 21,8\%, tetapi kadar HDL -Kolesterol meningkat 11,3\% (Seputra, 2008).

Berdasarkan hasil penelitian membuktikan bahwa pemberian sari tebu dapat berpengaruh untuk menurunkan kadar kolesterol darah, karena senyawa octacosanol yang terkandung pada sari tebu adalah alkohol lemak rantai yang panjang yang diperoleh dari tanaman atau semacam zat lilin dalam beberapa minyak tumbuhan serta merupakan salah satu komponen utama dari ekstrak tebu. Octacosanol dalam per harinya dapat menunjukan penurunan low-density lipoprotein (LDL) kolesterol sebesar 21\% $29 \%$ dan menaikkan kolesterol high-density lipoprotein oleh 8\%-15\%.

Ester lilin yang dihidrolisis oleh esterase empedu garam tergantung pankreas karboksil, melepaskan alkohol rantai panjang dan asam lemak yang diserap dalam saluran pencernaan. Studi metabolisme alkohol lemak dalam fibroblas menunjukkan bahwa alkohol lemak rantai yang sangat panjang, aldehid lemak, dan asam lemak adalah reversibel antar dikonversi dalam siklus alkohol lemak. Laporan manajemen diet penyakit ini mengkonfirmasi bahwa alkohol lemak rantai sangat panjang mengerahkan peran regulasi dalam metabolisme kolesterol dalam mengubah penyerapan LDL. 
Selain mengandung octacosanol sari tebu juga mengandung senyawa Saccharant yang berfungsi sebagai antidiabetes, sehingga aman untuk dikonsumsi oleh penderita diabet (kencing manis). Sari tebu juga telah diteliti dan ternyata banyak mengandung Vit B2 (riboflavin).

Tebu juga mengandung asam lemak yang memiliki efek anti radang dan analgetik. Ini dibuktikan dengan pemberian suatu campuran asam lemak yang diisolasi dari tebu kepada tikus. Tebu juga bersifat alkali sehingga dapat membantu melawan kanker payudara dan prostat (Subianto, 2005).

Kolesterol secara normal diproduksi sendiri oleh tubuh dalam jumlah yang tepat. Tetapi ia bisa meningkat jumlahnya karena faktor pemilihan makanan yang kurang tepat seperti makanan yang tinggi lemak dan sumber kolesterol (seperti makanan berminyak, bersantan, makanan fast food), alkohol dan gula yang berlebihan karena kelebihan kolesterol (Hiperkolesterolemia) dapat menimbulkan penyakit yang membahayakan seperti PJK atau stroke. Dalam hal ini mengkomsumsi sari tebu murni secara teratur pilihan yang tepat untuk menjaga metabolisme tubuh kita dari kekurangan cairan sehingga dapat terhindar dari stroke. Selain sari tebu harganya cukup ekonomis, mudah didapatkan dan dapat juga sebagai salah satu bahan alternatif dalam mencegah penyakit jantung mematikan khususnya penderita hiperkolestrolemia.

\section{KESIMPULAN}

Berdasarkan pembahasan dan hasil penelitian maka dapat disimpulkan : Rata rata kadar kolesterol darah sebelum perlakuan pada kelompok kontrol adalah $150 \mathrm{mg} / \mathrm{dl}$ dan nilai rata - rata kadar kolesterol darah setelah perlakuan pada kelompok adalah 148.8750 mg/dl. Rata - rata kadar kolesterol darah sebelum pemberian sari tebu pada kelompok perlakuan adalah 135,0625 mg/dl dan nilai rata - rata kadar kolesterol darah setelah pemberian sari tebu pada kelompok perlakuan adalah 118,25 mg/dl. Terdapat pengaruh pemberian sari tebu terhadap kadar kolesterol pada mencit.

Saran Bagi Masyarakat Untuk penderita hiperkolesterolemia tetap disarankan lebih hati-hati dalam memilih pola makan serta lakukan kebiasaan berolahraga. Melakukan pengontrolan pemeriksaan kadar kolestrol setiap 1 bulan sekali. Pemeriksaan rutin terhadap kadar kolesterol sebaiknya dilakukan juga pada orang-orang yang beresiko karena riwayat keluarga kolesterol.Bagi orang yang beresiko tinggi terhadap kolesterol, sebaiknya pemeriksaan dilakukan setahun sekali atau sebulan sekali. Bagi Peneliti lain Dapat melakukan penelitian lebih lanjut tentang manfaat yang terkandung dalam sari tebu untuk penyakit lain. Dapat melakukan penelitian lebih lanjut tetang berapa kosentrasi pada sari tebu yang dapat menurunkan kadar kolesterol darah secara signifikan dan jenis kolesterol secara spesifik yang dapat diturunkan setelah pemberian sari tebu. 


\section{DAFTAR PUSTAKA}

Adisewojo, S. 1983. Bercocok tanam tebu. Sumur Bandung, Bandung.

Anung, 2012. Apa itu Kolesterol,Gejala Kolesterol Tinggi,Apa Penyebabnya dan Cara Menurunkannya. www.Anungblog.com. Diakses 7 Januari 2012.

Anonim, 2006. Hidup Bebas Tanpa Cemas. http://www.who.int/whosis/mortsearo-idn-indonesia.pdf. Diakses tanggal 9 Juli 2006.

Atjung. 1985. Aneka Tanaman Industri. Bumi restu PT, Jakarta.

Dalimartha, S. 2000. 36 Resep tumbuhan obat untuk menurunkan kolesterol. PT Penebar Swadaya, anggota I Kapi. Jakarta.

Harmanto,N.2005.Mengusir Kolesterol bersama Mahkota Dewa. Agromedia pustaka. Jakarta.

Hidayat A.Aziz. 2008. Metode Penelitian dan Analisis Data. Salemba Medika, Jakarta.

Kusumawati, Diah. 2004. Bersahabat Dengan Hewan Coba. Gajah Mada University Press. Yogyakarta.

Kee, J. 2007. Pedoman Pemeriksaan Laboratorium dan Diagnostik. EGC. Jakarta.

Muhammad, A. 2009. Waspadai Kolesterol Tinggi. Buku Biru. Jogjakarta.

Muljana, W. 1995. Teori dari Praktek Cocok Tanam Tebu Dengan Segala Masalahnya. Aneka Ilmu. Semarang.
Nugraha, J. 2007. Tehnik pengambilan darah vena dan kapiler. Surabaya

Pangastuti, H. 2011. Kolesterol \& Lemak Itu Penting. Hanggar Kreator. Yogyakarta.

Pranawati, F. 2007. Pedoman Mengenal \& Menjaga Kolesterol. Pionir Jaya. Bandung.

Sayuthi, D. 2007. Uji Coba Monyet Diprotes". www.wordpress.com. Diakses 7 Oktober 2007.

Subianto, T. 2005. Manfaat Air Tebu. www. TeguhSubiantoblogspot.com. Diakses 23 Januari 2005.

Seputra, Y. 2008. Manfaat Tebu. www.csis.or.id webmaster. Diakses tanggal 05 Januari 2008.

Sholekhudin, M. 2006. Jangan Lupakan Jasa Hewan Coba. www.Sholekhudinblogspot.com. Diakses 5 Oktober 2006.

Sodo, Adisewojo, 1991. Bercocok tanam tebu. PT Bale. Bandung.

Yatim, F. 2010. Cara Ampuh Mengontrol Kolesterol. Sarana Pustaka Prima. Jakarta. 